\title{
Prison Commitment in the Implementation of the Scabies Management Program in Class II A Prison Rantauprapat
}

\author{
Ida Rizkia ${ }^{1}$, Zulfendri ${ }^{2}$, Taufik Ashar ${ }^{3}$ \\ 1,2,3 Faculty of Public Health, Universitas Sumatera Utara, Medan, Indonesia \\ Email: idarizkia233@gmail.com
}

\begin{abstract}
:
Scabies is a contagious skin infection caused by infestation and sensitivity to Sarcoptes scabiei varietahominis which is included in the Arachnida class. Data obtained from the Class II-A Prison clinic that the disease that is often experienced by prisoners is a skin disease such as scabies. The policy for scabies prevention and prevention in Class II-A Prison Rantauprapat has been pursued in 2017, but these efforts have not yet yielded encouraging results, because the number of scabies sufferers continues to increase each month. The purpose of this study is to see the commitment of prisons in the implementation of scabies program in Class II-A Prison in Rantauparapat. This qualitative research method uses case studies with in-depth interviews and includes various sources of information. There were five informants in this study, namely 1 Head of Class II-A Prison Rantauprapat, 1 prison Doctor, 1 prison Nurse, 2 prison. The results showed that the commitment of the prison party was quite low so that the implementation of the scabies program in Class II-A Prison Rantau Parapat was not going well.
\end{abstract}

\section{Keywords:}

clinical rotation; clinical setting; forensic medicine; medical humanities

\section{Introduction}

Health services in Indonesia are implemented in stages, starting with basic health services by first-level health facilities. Second-level health services can only be provided upon referral from first-levelhealth services. Third level health services can only be provided on reference to second or first level health services, except in emergenciesPermenkes RI No. 001 of 2012. (Sari, 2020).

Scabies is a contagious skin infection caused by infestation and sensitivity to Sarcoptes scabiei varieta hominis which is included in the Arachnida class (Jasmine, 2016). Scabies is easily spread in dense residential environments such as prisons or correctional institutions (Lapas). Scabies Prevention and Disease Prevention Strategy Policy Program in Class II-A Rantauprapat Prison that has been carried out once a week or every Friday cleaning activities are carried out by brushing the bathroom floor using soapy water from the prisoner's own joint funds (inmates do not use footwear when go into the bathroom, a lot of food debris littered on the bathroom floor). Some prisoners rarely bathe, due to the limited water flow in prisons, coupled with low personal inmate hygiene (many prisoners take baths only once a day).

Data from Class II-A Prison Rantauprapat that currently the number of prisoners in June 2018 was 1,692 people (1623 men, 69 women) while the capacity was 370 people. This shows that the amount of prison occupancy is not in accordance with the available capacity (over capacity). The density of prison occupancy affects the transmission of scabies (Class Prison II-A Rantauprapat, 2018) 
The rooms in Class II-A Rantauprapat Correctional Institution consist of Block A, Block B, the Narcotics Block, the Orientation Room (new prisoners), the hall room, and the children's block. There are 10 rooms in Block A (each room should have 6 people but 23 people with only 1 ventilation). Block B as many as 10 rooms (supposedly inhabited by 12 people turned out to be inhabited by 49-59 people with 1 ventilation). Narcotics Block as many as 10 rooms (supposed to be inhabited by 8 people, apparently inhabited by 34-39 people, with 2 ventilation). The $6 \times 3$ meter orientation room (new detention room) should have 15 people but 58 people with 2 ventilation. The Hall Room, due to lack of rooms, was occupied by 170 people. Blok Anak should have 8 people, but 38 people.

The problem of minimal funding or budget also becomes an obstacle in the implementation of scabies prevention and control programs. Based on the results of interviews with doctors and nurses in prison that the medicine budget is only Rp.2,000,000.per month, while inmates who check up more than 100 people per day for all types of diseases handled in Class II-A Prison Rantauprapat such as Pulmonary TB, HIV / AIDS, and other diseases.

The prison has made scabies prevention and control program based on the Decree of the Director General of Corrections of the Ministry of Law and Human Rights of the Republic of Indonesia Number PAS-31.PK.01.07.01 of 2016 concerning TB, Hepatitis, Scabies, Leprosy and Other Communicable Disease Control Standards (Kemenhumham) RI, 2016).

According to a classification issued by the World Health Organization (WHO), scabies is classified as water-related disease. Based on WHO data, the prevalence of scabies worldwide is reported to be around 300 million cases per year. In some developing countries, the prevalence of scabies is reported to range between $6-27 \%$ of the general population (Christy, 2015). In Brazil, South America the prevalence of scabies reached 18\%, in Benin West Africa $28.33 \%$, in the city of Enugu Nigeria 13.55\%, in Penang Island Penang 31\% (Aminah, 2015).

The prevalence of scabies in Indonesia is around 6-27\% of the general population and tends to be higher in children and adolescents, and lately there has been an increase in cases in adults (Ma'rufi, 2015). Data from the Ministry of Health of the Republic of Indonesia (Ministry of Health of the Republic of Indonesia) that in Puskesmas throughout Indonesia in 2013 that the prevalence of scabies was 4.6\% - 12.95\% and scabies ranks third of the 10 most common diseases. Data on the skin and genitals of FKUI-RSCM in the same year 704 cases of scabies were found, which was 5.77\% of all new cases. In 2011 and 2012, the prevalence of scabies was $6 \%$ and 3.9\% (Khairani, 2015).

Scabies generally infects and attacks individuals who live in groups such as in dormitories, boarding schools, correctional institutions (detention centers), hospitals, congested settlements and nursing homes. Correctional institutions or more commonly known by the word detention house or prison is always identified with a crowded room, not so well maintained and lack of ventilation because it is very possible for the emergence of various diseases. Inadequate prison conditions certainly become a risk factor for various infectious diseases or not. The detention environment which is usually not well maintained or the use of unclean water often causes skin problems such as itching, allergies or dry skin (Pasaribu, 2013). 
The high prevalence of scabies in Prison according to research by Humananada (2014) is due to the fact that the condition of the facility is not yet fully optimal, occupancy density, habits that are less clean and personal hygiene is not maintained. Other factors that can cause and help spread scabies include water, a low economy, density, sanitation, sexual relations, individual behavior and poor personal hygiene. Knowledge and attitude about personal hygiene affect the incidence of skin diseases because personal hygiene greatly determines health status, where individuals consciously and on personal initiative maintain health and prevent disease. In addition, scabies is closely related to individual behavior that does not support clean and healthy living behavior (Jasmine, 2016).

The results of initial interviews conducted by researchers on health workers (doctors and nurses in prison) that their symptoms are red skin, irritation, runny bubbles, and itching, especially at night. Most sufferers experience scabies between their fingers and toes, elbows, groin and around the genitals, groin, lower abdomen, buttocks, and waist. Scabies prisoners are not differentiated from other prisoners who do not suffer from scabies, like HIV sufferers. But for prisoners with pulmonary TB, the room is separated from other inmates because it is feared that it will quickly infect other patients.

The commitment of prisons in the prevention and control of scabies in Class Prison II-A Rantauprapat has been pursued in 2017 by inviting health workers from puskesmas and Rantauprapat Health Offices to conduct counseling or health education, conduct clean and healthy life behavior (PHBS) activities by cleaning the room in mutual cooperation, providing treatment on a regular basis, but these efforts have not yet reached encouraging results, because the number of people with scabies every month continues to increase. Dense housing, lack of socialization, inattention of prisoners to personal hygiene also drives the spread of scabies in prisons.

Prison commitment in the prevention and prevention of Scabies Disease in Class II-A prison Rantauprapat which has been done once a week or every Friday cleaning activities are held by brushing the bathroom floor using soapy water derived from a joint fund of the prisoners themselves (prisoners do not use footwear when go into the bathroom, a lot of food debris littered on the bathroom floor). Some prisoners rarely bathe, due to the limited water flow in prisons, coupled with low personal inmate hygiene (many prisoners take baths only once a day). There is a provision from the prison that each prisoner carries only 5 pairs of clothes, but in fact almost all prisoners carry more than 5 pairs of clothes so there is a buildup of dirty clothes and a chain of transmission of scabei bacteria and a common health problem in prisons. Occupational conditions dense and low personal hygiene is an effective source of transmission increasing the prevalence of scabies.

Preliminary survey conducted by researchers conducted interviews with 10 prisoners who experienced scabies by asking about the causes and ways of preventing scabies, only 2 people who can answer correctly, while 8 others answered incorrectly or incorrectly. The eight people answered differently, 4 people stated that the cause of scabies was due to a virus, 3 people answered because of infection, 1 person answered scabies transmitted due to sex, 5 people said prevention of scabies by giving fragrances to clothes and sheets, 3 people answer don't know. This indicates that prisoners' knowledge of scabies and prevention is largely lacking. Researchers suspect that the increase in the number of patients with scabies experienced by prisoners in Class Prison II-A Rantauprapat is caused by many factors, but the commitment of prisons in scabies prevention and prevention efforts is one of the things that is very important for the success of scabies prevention programs in prisons. 
Dense housing, lack of socialization, inattention of prisoners to personal hygiene are also driving the spread of scabies in prisons. This is based on preliminary interviews conducted by researchers at the Head of Class II-A Prison Rantauprapat.

Policy Strategy taken in the treatment of Class II-A Dilanta Rantauprapat scabies due to the limited amount of drugs with a lack of budget, namely given Ointment K-24 or also scabimite ointment given little by plastic per person, then the antibiotic drug Citirizine, Amoxicilin, Tetracyclin tablets and Chlorpheniramin Maleate or Chlor Trimeton Maleate (CTM) as well as 2 tablets of dexamethasone tablets for 5 days of use. Sulfur should be given to prisoners who suffer from scabies but because of the budget it is not possible to give sulfur to these prisoners.

\section{Reseach Method}

This type of research is a qualitative method using case studies with in-depth interviews. The study was conducted in Class II-A Prison Rantauprapat Informants in this study as many as 5 people, namely 1 Head of Class II-A Prison Rantauprapat, 1 Prison Doctor, 1 Prison Nurse, 2 prison.

In this study what is important for researchers is not the number and number of informants, but rather the researchers prefer the quality of informants. In a sense, more mastered information to be obtained from the research area. Therefore, researchers allow to take informants in large numbers based on the principle of the depth of the excavation of informants about the prevention and control of scabies in Class II-A Prison Rantauprapat. Data were analyzed, namely data reduction, data presentation and conclusion drawing.

\section{Result and Discussion}

Based on the results of the study showed that the scabies prevention and control program to date at the Class II-A Prison Rantauprapat is not running optimally. Based on data that the number of patients with scabies in 2018 was 378 people $(22.34 \%)$ increased when compared to the 2017 data which was $362(21.17 \%)$. The number of sufferers is based on prisoner visit data at the polyclinic which means the high number of scabies patient visits at the polyclinic is not proportional to the number of health workers available, namely 1 prison doctor (newly graduated), 2 PTT doctors, and 4 nurses. Scabies patient visits in the Polyclinic as many as 30-41 people per day. As stated by the informant:

"The number of prisoners who suffer from scabies continues to increase in number, compared to last year, we here health workers are also very less when compared to the number of sufferers and prison residents. Health workers are only 3 doctors and 4 nurses. Health facilities such as medicine are also lacking. Whereas the prison residents are already over capacity "(Head of Class II-A Prison Rantauprapat).

Correctional Institutions are correctional business units that accommodate, care for and foster prisoners. Prison is always identified with a crowded room, not maintained and lack of ventilation because it is very possible for various diseases. Prison and detention situations are generally overcapacity, causing a low sanitation system and environmental sanitation that contribute to the increased vulnerability of WBP to infectious diseases. One type of infectious disease experienced by prisoners in prisons is skin disease, namely scabies. 
The spread of scabies generally occurs through direct skin contact or through bedding (bed sheets, pillows), combs, clothing, towels, unclean water and dense occupancy. Thus, prisons that are densely populated are ideal environments for spreading scabies. Scabies is easily transmitted from human to human, from animal to human and vice versa. The high prevalence of scabies in correctional institutions is due to the fact that the condition of the facility is not fully optimal, habits that are less clean and personal hygiene is not maintained. Other factors that can cause and help spread scabies include water, a low economy, density, sanitation, sexual relations, individual behavior and poor personal hygiene.

In line with research conducted by Sunandar (Class II-A Prison Pontianak that health human resources in prison are still minimal and still lacking health workers. The quality of staff is expected to be able to carry out tasks according to their job descriptions and are also expected to be able to responding to challenges or problems that always exist in the Lapas environment.In general education officers can be said to have been adequate but in terms of carrying out HIV / AIDS prevention tasks not many officers are said to be competent, because in the recruitment of officers as correctional officers must necessarily with certain prerequisites. prospective employees have received some kind of education or training, in terms of HIV / AIDS prevention and control the quality of the staff can be said to be still lacking. broadly know how the transmission and how not to get infected. Because it is not impossible that officers can be infected.

In addition to the problem of minimal human health resources, the problem of minimal funding or budget also becomes an obstacle in the implementation of scabies prevention and management programs. Based on the results of interviews with doctors and nurses in prison that the medicine budget is only Rp. 2,000,000 per month, while prisoners who examine more than 100 people per day for all types of diseases handled in Class Prison II-A Rantauprapat such as pulmonary TB, HIV / AIDS, and other diseases.

"The budget for overcoming scabies here is very minimal. Only Rp. 2,000,000.- per month for all types of diseases from pulmonary TB, HIV / AIDS, scabies, and others. It's hard to carry out activities with such a small budget "(Doctor Class Prison II-A Rantauprapat)

Fulfillment of facilities and infrastructure of Correctional Institutions is a necessity that is inseparable from the implementation of the duties and functions of Correctional Institutions, so the unemployment policy must consider the risks arising from the nonfulfillment of these facilities and infrastructure. Good development planning is needed so that the overcrowding capacity of Penal Institutions can be overcome.

The prison environmental health development program is also an obstacle in scabies prevention and control. Prison commitment to deal with the transmission of scabies between inmates is not running optimally. Even though the prison facility holds a cleaning activity once a week, many prisoners do not participate in the cleaning activity. The programmed activities are cleaning the bathroom floor, washing dirty clothes, drying pillows and mattresses, boiling towels, but in fact these activities are not well realized. Many prisoners are reluctant to carry out these activities to clean up cell rooms, detention blocks, as well as prison cleanliness activities. In addition, some prisoners rarely bathe, due to the limited water flow in prisons, coupled with low personal inmate hygiene (many prisoners take showers only once a day).

"If its difficult here, if the prison organizes cleaning activities, rarely wants to move, just look at yourself, dirty and congested rooms, scattered rubbish, smelly and hanging 
clothes, many are lazy to take a shower, lazy to participate in mutual cooperation." (Class II-A Prison Rantauprapat)

There is a provision from the prison that each prisoner carries only 5 pairs of clothes, but in fact almost all prisoners carry more than 5 pairs of clothes so that there is a buildup of dirty clothes and a chain of transmission of scabei bacteria and a common health problem in prison. Dense housing conditions and low personal hygiene are effective sources of transmission, increasing the prevalence of scabies.

Management carried out by Class II-A Prison Rantauprapat in providing health services to prisoners suffering from scabies is the same as any other disease by conducting a skin examination and being given medicine. Efforts to prevent and control scabies by giving 24 ointments, anti-itching (cetirizine), amoxixilin antibiotics, and permethrin once a week for 3 weeks are given to prisoners who come to the Class II-A Prison Rantauprapat prison polyclinic but the drug is sometimes not given because of limited stock so they are often only given one of these drugs. According to prisoners suffering from scabies in Class II-A Prison Rantauprapat, the services provided by health workers at the Klasuprapat Klas II Prison Polyclinic have been carried out well, although they are still new.

Furthermore, related to the reporting process of the implementation of the prevention and control program of scabies in Class Prison II-A Rantauprapat, health workers have done it in accordance with the format of health (health and care), namely form 12A and 12B which are standard from Kemenkumham. The recording is done by nurses in Lapas Klasuprapat IIA based on the results of examinations carried out by class II-A Prison doctors. The report was compiled based on a medical record book and recorded all complaints of patients who came to the clinic in prison, not only about scabies but all diseases treated in Class Prison II-A Rantauprapat. Reporting is done every month to the Ministry of Law and Human Rights in North Sumatra on time, namely on the 5 th of each month.

\section{Conclusion}

The conclusion of this study is that Class II-A Prison Lapasuprapat lacks commitment in the prevention and control of scabies, related to the lack of health human resources, inmates themselves who are less concerned about personal hygiene, development of prison environmental health that is not running optimally as well as budget problems (funds) is a problem which is one of the causes of not achieving indicators in accordance with standards in accordance with Scabies control standards.

\section{References}

Agoes, R. (2015). Skabies ; Konsep Pencegahan dan Pengobatan pada Komunitas di Indonesia. Majalah Kedokteran Bandung.

Akib, H. dan Tarigan, A. (2010). Artikulasi Konsep Implementasi Kebijakan: Perspektif, Model Dan Kriteria Pengukurannya. Jurnal Kebijakan Publik.

Humananda N, Pranowowati P, Siswanto Y. (2014). Analisis permasalahan kesehatan pada narapidana di lembaga pemasyarakatan Klas IIA Ambarawa. Artikel Penelitian. Ambarawa: STIKES Ngudi Waluyo.

Jasmine, I.A. (2016). Hubungan Antara Pengetahuan Dan Sikap Tentang Personal Higiene Dengan Perilaku Pencegahan Penularan Skabies Studi Observasional Pada Narapidana Anak di Lembaga Pemasyarakatan Anak Klas IIa Martapura. Banjarmasin: Program Studi Kesehatan Masyarakat Fakultas Kedokteran, Universitas Lambung Mangkurat. 
Kemenhumham RI. (2016). Keputusan Direktur Jenderal Pemasyarakatan Kementerian Hukum dan Hak Asasi Manusia Republik Indonesia Nomor PAS-31.PK.01.07.01 Tahun 2016 tentang Standar Pengendalian TB, Hepatitis, Skabies, Lepra dan Penyakit Menular Lainnya.

Class Prison II-A Rantauprapat. (2018). Laporan Jumlah Penghuni Lapas bulan Juni 2018. Rantauprapat: Lembaga Pemasyarakatan Klas II-A Rantauprapat.

Peraturan Menteri Hukum dan Hak Asasi Manusia Republik Indonesia Nomor M.HH-07.OT. 03 Tahun 2011 tentang Rencana Induk Pembangunan Unit Pelaksana Teknis Pemasyarakatan Di Lingkungan Kementrian Hukum dan Hak Asasi Manusia

Sari, F. (2020). Referral Demand of Patients in Pantai Cermin Public Health Center Langkat. Britain International of Humanties and Social Sciences (BIoHS) Journal. P. 314-320.

Sunandar, A. (2014). Efektivitas Pelayanan Kesehatan Terhadap Narapidana Berdasarkan Peraturan Pemerintah Nomor 58 Tahun 1999 Tentang Syarat-Syarat Tata Cara Pelaksanaan Wewenang Dan Tanggungjawab Perawatan Tahanan Dalam Rangka Pemenuhan Hak Narapidana Di Lembaga Pemasyarakatan Klas II-A Pontianak. 